Comparative Philosophy Volume 12, No. 1 (2021): 30-54

Open Access / ISSN 2151-6014 / www.comparativephilosophy.org

https://doi.org/10.31979/2151-6014(2021).120106

\title{
GAPS: WHEN NOT EVEN NOTHING IS THERE
}

\author{
CHARLES BLATTBERG
}

\begin{abstract}
A paradox, it is claimed, is a radical form of contradiction, one that produces gaps in meaning. In order to approach this idea, two senses of "separation" are distinguished: separation by something and separation by nothing. The latter does not refer to nothing in an ordinary sense, however, since in that sense what's intended is actually less than nothing. Numerous ordinary nothings in philosophy as well as in other fields are surveyed so as to clarify the contrast. Then follows the suggestion that philosophies which one would expect to have room for paradoxes actually tend either to exclude them altogether or to dull them. There is a clear alternative, however, one that fully recognizes paradoxes and yet also strives to overcome them.
\end{abstract}

Keywords: atomism, contradiction, monism, nothingness, paradox, pluralism, reconciliation, separation, transformation

\section{INTRODUCTION}

My argument is that "gaps" consist of a radical form of meaninglessness, one that derives from paradox. I begin by showing how they should be associated with a certain conception of "separation." It is one best understood not in mereological terms, those that invoke parts and wholes and divide atomists from holists, since atomists go no further than conceiving of separation along the lines of discreteness, that is, as arising from sharp, solid boundaries. Separation in the more radical sense invokes instead the classic theme of "the One and the Many," which divides monists from pluralists: to the former things cohere, together exhibiting a oneness, whereas to the latter they are many and fragmented. Given this theme, we can understand radical separation as implying gaps and so pluralism, or at least disunity. I will then suggest a novel (at least for prose) way of representing gaps, followed by the claim that there's a sense in which they refer, not to nothing, but to less than nothing.

It's for this reason that gaps should be contrasted with the many non-paradoxical conceptions of nothingness, some examples of which I will enumerate. They are not paradoxical because paradoxes are unlike ordinary contradictions in that they must be

BLATTBERG, CHARLES: Professor of Political Philosophy, Université de Montréal, Canada, charles.blattberg@umontreal.ca 
not only disunified, hence incompatible with monism, but also mereologically holist rather than atomist. The essay then concludes with the suggestion that, while nonmonist philosophers (nihilists excepted) certainly have room in their thinking for disunity, some miss the relevance of paradox altogether, while others have allowed their paradoxes to become dulled. There is a third way, however, one that both recognizes and strives to overcome paradox.

Before continuing in this metaphysical vein, however, I want to offer two vivid, indeed personal, examples of gaps. I encountered the first at age nineteen, when my father died. Since then my heart has had a hole in it, a wound that just will not heal. So I could only nod along sadly while reading Magdalene Redekop on the loss of her husband: "The heart does break and something in you dies when your mate dies. The broken pieces are beyond fixing and time does not heal them. People are wrong about that." $(2013,11)$. While it's possible to complete a bereavement process, this does not mean the grieving necessarily ends; one grieves a loss, after all, and the loss remains. ${ }^{1}$ But at least it is (usually) not total. The horror of categorical violence such as genocide is that it aims for precisely such total destruction: for the complete erasure of its victims, including any memory of them, from history, from being. ${ }^{2}$

Every person's death amounts to the loss of an individual capable of producing meaning, and so of a potential interlocutor. For those left behind, it's as if someone they have or could have addressed has been struck forever silent. So this is one way of recognizing that something significant has gone missing, a feeling that ends only when the survivors, too, pass away. Whence Ram Mohan Roy: "Just imagine how terrible it will be on the day you die / Others will go on speaking, but you will not be able to respond" (Sen 1999, 179).

Not that such morbid gaps are never welcome. But even when a death provides benefit, something meaningful is always lost. Here's the conniving French diplomat Talleyrand upon hearing of a rival's demise: "I wonder what he meant by that?" This is funny not only because it treats someone's death as a move in a diplomatic game, but also because it questions the significance of something that is inherently insignificant. For that is what gaps of meaning "are."

My second example is far less morbid: that hoped-for when one is caught doing something shameful. The idea is that your act might somehow be made meaningless to others and so no longer exist for them, thereby providing a kind of escape. Shameful acts, in other words, cry out for gaps to obscure them. As Bernard Williams remarks:

In my experience of shame, the other sees all of me and all through me, even if the occasion of the shame is on my surface - for instance, in my appearance; and the expression of shame, in general as well as in the particular form of it that is embarrassment, is not just

\footnotetext{
1 “'Completion' is helpful in denoting relative resolution, but it suggests that there is a fixed endpoint of the bereavement process after which there is no more grieving, a notion that is inaccurate ... [When the outcome is favourable, people] do adapt and stabilize, yet clinical observers of the bereaved have found that some of the pain of loss may remain for a lifetime." (Osterweis, Solomon, and Green 1984, 52).

${ }^{2}$ This is why the Nazis, for example, forced their victims to undergo a process of "depersonalisation" before murdering them (Blattberg 2009a, 47-48; and Blattberg 2009b, 198-99).
} 
the desire to hide, or to hide my face, but the desire to disappear, not to be there. It is not even the wish, as people say, to sink through the floor, but rather the wish that the space occupied by me should be instantaneously empty. With guilt, it is not like this; I am more dominated by the thought that even if I disappeared, it would come with me (Williams 1993, 89).

That what is hoped-for here amounts to a gap should be evident, since people don't just disappear - not physically, anyhow. So the wish to do so is equivalent to an aspiration for a contradictory existence that would be truly extraordinary, since one would both be there and not there at the same time.

\section{TWO CONCEPTIONS OF SEPARATION}

When Aristotle (2001, 325a7-8) claims that entities can only be separated by something, since otherwise there would be nothing to keep them apart, he assumes the word "separation" must have a strictly mereological meaning, the one that supports a form of independence and so the discreteness characteristic of atomism. Locke does the same. When he suggests that there are more "separated and diversified" species of spirits above us than there are such species of sensible and material things alongside us, he assumes that, in all cases, "we see no Chasms, or Gaps" between them (1975, III.vi.12). Evidently, he intends by this that there are at most - or rather least conceptual lines to be drawn.

Separation in this sense is also behind how the term tends to be used in contemporary physics, as with Einstein's assumption that "spatiotemporal separability" is a sufficient condition for physical individuation. The idea, which Einstein came to regard as central to his conception of physical reality, likely had its most immediate source in Schopenhauer's claim that space and time are the basis of the principium individuationis. But its origins lay with what I would identify as monist versions of classical atomism, the doctrine that fundamental reality consists of no more than atoms and void (Howard 1997, 88, 115, 138). It is because monist philosophers assume the connection between things that they deny gaps. ${ }^{3}$ So when classical atomists also subscribe to monism, they must assume that the void exists no less than the atoms. This is why, as Aristotle describes the position of the ancient Atomists Leucippas and Democritus, for instance, "there is a void" (2001, 325a32; my italics); or, as Hegel puts it, there is an "existing nothing in between the atoms" (2010, $\S 98$, Addition 1; his italics). We can say something similar about those uses of "separation" implying division based on a principle, as when Thomas Jefferson declares that there is "a wall of separation between Church \& State" (1998), or when Michael Walzer extends this

\footnotetext{
${ }^{3}$ Not that this is consistently a bad thing. Think of the associations between Socrates' monist belief in the immortality of the soul, the courage he showed in drinking the hemlock, and his inability ever to truly listen to his interlocutors (Blattberg 2009c).
} 
idea to distributive justice as a whole by virtue of what he calls the "art of separation" (2007). ${ }^{4}$

In contrast to this "mending wall" separation, as we might refer to it, there is also a more radical sense of the word. It implies separation by Nothing or Nonbeing and, because of this, disunity. The capital Ns come from Blaise Pascal, Stéphane Mallarmé, and Paul Valéry, ${ }^{5}$ and they help to distinguish this sort of separation from the "nothings" that imply something - as Augustine believed they must always do ${ }^{6}$ and as the monk Fridugisus of Tours $(1995,5)$ concurred when he argued that there can be no empty words, since God has created an object for every one of them.

This points directly to what seems a key problem, however. Often, the idea of nothing is expressed with a word, whether capitalized or not; a sentence, as in contemporary physics' definition of nothing (i.e., no universe) as "a closed spacetime of zero radius"; or a symbol, such as the zero (0) of mathematics or the empty set ( \{\} or $\varnothing)$ of logic. But all such representations necessarily invoke something meaningful, whereas what I intend is precisely meaningless. ${ }^{7}$

This is why, even though it too strikes me as ultimately inadequate, I want to suggest that we use none other than " " to greet this unnameable opposite of Being, to paraphrase Jacques Derrida $(1978,79)$. For , I claim, implies what John Sallis (1987, ix, xvi) has called "separation as such," that is, separation by a space truly "beyond being," one that "is" genuine Nonbeing and, because of this, entails neither mediation nor immediacy, to paraphrase Derrida $(1978,79)$ again.

Western mysticism is a major source of this idea. When the Jewish Kabbalists offer their version of creation ex nihilo, for example, they invoke the first and highest of God's ten powers (sefirot), the one they call "Nothing" (ayin). It can also be found in the cosmogony developed by Isaac Luria, the sixteenth century mystic from Safed (Scholem 1974, 265-68). According to Luria, the light of creation which emanated from God in a chaotic, atomized form had to be contained in bowls or vessels, some of

\footnotetext{
${ }^{4}$ As Walzer also writes: "In any differentiated society, justice will make for harmony only if it first makes for separation. Good fences make just societies" (1983, 319).

${ }^{5}$ As Pascal writes, "For in fact what is man in nature? A Nothing in comparison with the Infinite, an All in comparison with the Nothing, a mean between nothing and everything. Since he is infinitely removed from comprehending the extremes, the end of things and their beginning are hopelessly hidden from him in an impenetrable secret; he is equally incapable of seeing the Nothing from which he was made, and the Infinite in which he is swallowed up" (2003, § II, no. 72). For Mallarmé, see below. And according to Valéry, "-The very thirst that made you huge / Can raise to the power of Being the strange / Allprobing force of Nothingness!” $(2007,205)$.

${ }^{6}$ To Augustine, "nobody uses words except for the sake of signifying something. Thus every sign is also some thing, for what is no thing is nothing at all." $(1995,164)$.

7 "A closed spacetime of zero radius" is how Jim Holt expresses Alexander Vilenkin's idea $(2012,143)$. Alan H. Guth has done so this way: "imagine a closed universe, which has a finite volume, and then imagine decreasing the volume to zero" $(1997,273)$. On the same page, Guth equates this with "absolute nothingness," no doubt encouraged by Vilenkin's initial account of his idea as being about "literally nothing." But given what he says in a later work, Vilenkin appears to have become aware of the idea's limitations: "the state of 'nothing' cannot be identified with absolute nothingness" - one presumably beyond the meaningfulness that physics provides, given that "The laws of physics must have existed, even though there was no universe" $(2006,181)$.
} 
which were shattered in the process. This is why the world is "broken," and why we may also say that is, following Gershom Scholem, "the abyss which becomes visible in the gaps of existence" $(1974,217){ }^{8}$

\section{NOTHINGS, SWEET AND SOUR}

In consequence, when I use the word "gap," or write , it is meant to bring to mind such "things" as the contents of that empty envelope Samuel Beckett once mailed to a literary critic (Brater 2010, 240-41). Indeed, as suggested, there's a sense in which is actually less than nothing - though I am aware that even the Mad Hatter considers this impossible. (Admitting that Alice can take more tea despite having had none yet, since "it's very easy to take more than nothing," he still insists that she "can't take less" [Carroll 1965, 84].) To me, however, a gap is indeed less than even both of the nothings invoked in Wallace Stevens' poem "The Snow Man," where we read of the "[n]othing that is not there and the nothing that is" (Stevens 1987, 8). ${ }^{9}$

Let's take a closer look at what Stevens might mean. "The nothing that is" is the one present, as we have just seen, in the thinking of the Atomists Leucippas and Democritus. For Plato (1989a, 236E-241B, 254D-258E), moreover, the many puzzles that arise the moment we try to speak coherently of nonbeing as the opposite of being should lead us to dismiss this sense of the term. Instead, he argues for one that equates it with otherness - that is, with what is not the case. Aristotle, for his part, refuses even this weak sense of nonbeing. Given his stance that every genus must consist of an identifiable domain, there can be no genus of everything since there would be nothing outside of this domain to allow us to specify it - so to invoke a contrast with nonbeing is, presumably, metaphysically absurd. Aristotle (2001b, 192a2-6) thus goes no further than recognizing nonbeing as the privation (sterēsis) of being, by which he simply means being shorn of a particular form. (Later, Augustine and others would go so far as to identify the privation of being as "evil.") Because to Aristotle (2001c, 1059b31; see also 998b21-24), "everything is and is one." Much later, Hegel would reiterate Plato's "nonbeing as a form of being" approach. In the first category of his logic, he shows how both pure being and pure nothing are indeterminate, lacking all quality (or rather this lack is their quality). And since they are both the same and different, they vanish into each other - part of the process of their sublimation (Aufheben) through "becoming" (Hegel 2010, 21.68-21.70).

As for Stevens' "[n]othing that is not there," think of what Macbeth must mean when he declares "nothing is but what is not" (Shakespeare 1977, I.iii.145). This is the kind of nothing "present" in two of twentieth-century phenomenology's three classical forms. Not Husserl's transcendental version, since it "wants to know nothing of the nothing," as Heidegger $(2008,96)$ complains. He thus saw his own hermeneutical phenomenology as taking a decisive step forward by virtue of its recognition that

\footnotetext{
${ }^{8}$ For more on Jewish mystical Nothingness, see Dan 1998-99; and Matt 2000.

${ }^{9}$ Perhaps the poem can, however, be said to invoke if we break up the lines beginning with "Of" between its first and third stanza.
} 
nothingness is the non-sense or absence of meaning constituting the world's necessary but ungraspable (because prereflective) background; indeed, it is none other than this background that makes all meaning, and so all "worldliness," possible. ${ }^{10}$ Later, Sartre's existentialist phenomenology may be said to begin with Plato's sense of nonbeing as that feature of our thinking which is simple negation, conceived in terms of the concrete absences in the world that we inhabit. We can both apprehend these absences - as when I see that Pierre, with whom I had a rendezvous, is not present in the café - as well as take responsibility for them. The existentialist approach ends, however, with nothingness as consciousness' very mode of being. This is why consciousness is a "being-for-itself," the particular nothingness that experiences itself as such; by contrast, the "being-in-itself" that is its object exemplifies being (Sartre 1956, part 1, ch. 1). ${ }^{11}$

It is because monist positions such as these have no "room" for gaps that, while they are certainly able to acknowledge disagreements between people, they cannot accept the possibility that some of them might be inherently irreconcilable. We might even say that, while they have room for "sweet" nothings, those contradictions which do not offend reason, they have none for the unpalatable "sour" kind. The latter, however, are precisely what I think Stevens means to evoke when, in another poem, he declares that "There is a conflict." Because it is "The Course of a Particular" to struggle against becoming - just as those leaves do, the ones that manage to cling to their trees throughout winter, since it is only when they finally fall that "the nothingness of winter becomes a little less" (Stevens 1997b, 460).

Let's review some more nothings that ought to be distinguished from . I'll begin with three possible senses of "void": that of mathematical unoccupied space; that of physical unoccupied space; and that of practical emptiness, the kind which makes a jug or flask capable of holding liquid (Heidegger 1971a, 169; Sedley 1982, 175). Unlike the one my father's passing left in my heart, this last type of hole has nothing disorienting about it: it is simply an immaterial, existing thing with properties. (For example, it has a definite radius, thickness, volume, and location.) But interestingly, monists who have tried to give strictly topological accounts of such holes seem to have stumbled on a route to gaps, and so, since this approach can easily lead to incoherencies. $^{12}$

\footnotetext{
${ }^{10}$ On how Heidegger's lecture as a whole can be read as making the accusation of Husserl, see Welton 2002, 124-25. Already in division two of Being and Time, Heidegger showed how we are inherently related to this nothingness given our "being-towards-death" (1962). But as this is not the of the gap (or at least that's my claim), Heidegger's conception of dying cannot be said to involve the kind of conflict and fundamental aloneness that I have described. Should there be any doubt about this, note his assertion that the nothing "is nothing" (Heidegger 1987, 2; his italics).

${ }^{11}$ It is because Sartre's two fundamental ontological categories of being-in-itself and being-for-itself are united, there being a "synthetic connection" $(1956,785)$ between them, that his ontology should be considered monist. I discuss Heidegger's monism in Blattberg (forthcoming).

${ }^{12}$ Hence the various mysteries surrounding the holes discussed by Achille C. Varzi (2015). As Varzi explains, if we take account of no more than an object's surface, its intrinsic topology, then we will be led to the eliminativist claim that to speak of a hole in something is merely to say that it is perforated, i.e. that holes are not entities in their own right. But if we instead include how the object exists in 3-D space, its extrinsic topology, then we may also refer to its complements. This, he tells us, allows us to
} 
Gaps must also be distinguished from the existential nihilist's assertions of meaninglessness, directionlessness, or insignificance, which are based on no more (or rather no less) than the leveling of standards. ${ }^{13}$ The "stuff" of gaps is likewise not what Mahāyāna Buddhists mean when they invoke "emptiness" (śünyatā) to express the idea that beings have no intrinsic properties. Nor is it comparable to the notion of "absolute nothingness" ( $m u$ ) developed by Nishida Kitarō and the rest of the Kyoto School, drawing on Zen's combination of Mahāyāna emptiness with Taoist "nothingness" $(w u) .^{14}$

The meaningful absences frequently employed in the contemporary arts are also far from gaps. Silence in music, for instance, can be very meaningful indeed: think of the pause just before the final hallelujah in Handel's "Messiah" (Harris 2005, 521), not to mention John Cage's classic "4'33"” (Marx 2010). Such silence "is unidimensional acoustically (defined only by its length) but multidimensional perceptually (describable as tense, relaxed, too short, arresting, or disturbing, e.g.)," as one musicologist (Margulis 2007, 246) puts it, with others (Ricci et al. 2005) describing it as "one of the colours on the composer's palette" - all of which helps explain why a third (Clifton 1976,163 ) insists that this silence "is not nothing. It is not the null set." 15 Or as Cage $(2011,109)$ himself puts it as regards the silences in his work, "I have nothing to say and I am saying it."16

focus on the surface of the object's holes and so count all the holes that are present as well as tell the difference between straight and knotted holes. But that begs the question, because what are the complements? To answer, we must perceive in an everyday, practical sense rather than topologically.

${ }^{13}$ Awareness of this form of nihilism's threat entered modernity through Pascal's proto-existentialist writings, as when he declares: "In comparison with these Infinites all finites are equal, and I see no reason for fixing our imagination on one more than on another" (Pascal 2003, § II, no. 70). Later, Kierkegaard complains that the spread of disinterested reflection and invasive curiosity have produced an era characterized by the leveling of status and value (1978). And to Nietzsche, this flattening arises from the questioning of our fundamental, orienting values that follows the death of God $(2001, \S 108$, $125,343 ; 2006, \S 125)$. For helpful commentary on Nietzsche, see Katsafans 2015. More recently, Brassier appears to argue that this nihilism is not a threat but something (or rather nothing) to be embraced (2007, ch. 7). Following a point made long ago by Valéry, however, one has to wonder how Brassier managed to get out of bed and write his book: "If I feel that all is vanity, the very thought prevents me from writing it down" (Valéry 1968, 96). Note that gaps should also not be equated with the ontological nihilist's "there is nothing at all," even though this "nothing" is indeed . Because if what's contained in a gap is to "be" (or "not to be" - the contradiction, again, is intentional), then the gap must obviously be situated between beings; and beings are, by definition.

${ }^{14}$ On Mahāyāna emptiness, see Garfield 2015, ch. 3. To Kitarō, absolute nothingness is the selfcontradicting place (basho) wherein beings' specific properties are manifested $(1987,68-69,71,86-87)$. See also Heisig 2001, § 17.

${ }^{15}$ Other notable musical silences include those in the first movement of Beethoven's Pathétique sonata (1798); the two silent beats at the end of Mahler's "Der Abschied" (1912); and the dead stops in Steve Harley \& Cockney Rebel's "Make Me Smile (Come Up and See Me)" (1975). Regarding these examples, see Cooper 2011, 28; Peatti 2015, 58, 187; and Guarisco n.d., respectively.

${ }^{16}$ William Brooks nicely sums up Cage's approach: "silence, the musical equivalent of 'empty space' (an 'empty music') is - regardless of its metaphysical attributes - an experience, not the absence of one." $(2007,98)$. 
In literature, Mallarmé similarly broke new communicative ground with his poetry of absence. Such work came to have a powerful influence on Valéry, T.S. Eliot, and Paul Celan, among many others. ${ }^{17}$ As Michel Deguy points out, however, "'Nothingness', with Mallarmé, oscillates between Nothing and something-which-isnothing, 'a nothing'. It is nothing, we say in order to say something: 'Rien, cette écume'" $(1998,25)$. This oscillation is why, especially when we focus on these absences' form as distinct from their content, they can lead not to meaningful nothings but to incoherencies, gaps, and so . "I utter the word," Mallarmé writes, "so as to plunge it back into its own futility" (1998a, 482; my translation).

Monists miss this, as we can see from Sartre's reading of the poems. He takes Mallarmé at his word about following Hegel, using this as a key to unlock their mysteries. This makes them into "the fruitless outlines of an impossible and unheardof masterpiece which an untimely death prevented [Mallarmé] from undertaking. Everything falls into place if one considers these symbolic suicides in the light of an accidental death, and Being in the light of Nothingness" (Sartre 1988, 144). The reason it all comes together is that this "Nothingness" is (ostensibly) no less than Hegel's negation of being; that is why, when Sartre describes one of Mallarmé's poems as "a hole pierced in Being" $(1988,141)$, he does so merely to delimit it as the location of a Platonist "what is not the case." The only major difference Sartre sees from Hegel, though obviously significant, is that the Absolute in this case is none other than Mallarmé himself. ${ }^{18}$

Charles Taylor offers a similarly monist interpretation. For him, Mallarmé invokes "le néant" as part of the struggle, which began with Romanticism, to retain language's "expressive-constitutive" power, preventing its total collapse into the banal, inauthentic ordinariness of its "designative-instrumental" mode (Taylor 2016).

But surely there is more (or rather less) to it than this. When Mallarmé famously declares concern with "the Orphic explanation of the Earth" (1998b, 788; my translation) to be the poet's central duty, he is referring to creation, which is always to some degree irrational, not interpretation. Taylor blurs the differences between the two, as when he claims that Mallarmé's "nothing is the place of the logos" or that "what poetry strives to articulate" is "the true meaning of things" (Taylor 1989, 441; 2014, 71; see also 2007, 724-26). ${ }^{19}$ Essentially, the problem is that this misses Modernist creativity's reliance on inspirations that come through openings of . These are much more - or again rather less - than simply places "of radical indeterminacy," which is how Taylor $(2014,69)$ describes the "Nothing" that he associates with both Mallarmé and Paul Celan's apophatics of negative theology. What Taylor should be saying instead is that while the Nothing may have a location, it is not a place, and certainly not one where beauty might be encountered. Because as Mallarmé writes, "after having found Nothingness, I found Beauty" (Mallarmé 1998c, 701; my italics and translation).

\footnotetext{
${ }^{17}$ Writes Valéry, "Through the fissures in the All, the Nothing shows." (2011, 122). Regarding Eliot, Daniel Swift says that his "art lies in unfilled gaps." (2015). Celan will be discussed below.

${ }^{18}$ For the invocations of Hegel, see Sartre 1988, 48, 126, 130-31, 137, 142; and for the point about the Absolute being Mallarmé himself, see Sartre 1988, 127.

${ }^{19}$ For more on Taylor's blurring of creation and interpretation, see Blattberg 2009d.
} 
More generally, when Taylor describes the "interspatial" epiphanies of Modernism, he argues that they arise from a juxtaposition of images or words that let us triangulate towards meaning. But this seems to miss what's missing, namely the gap, since he explicitly equates such interspatial space with a "field" (Taylor 1989, 476-77; see also $420,466) .^{20}$

To understand why creation requires something other than just a place, it's worth looking more closely at what Mallarmé might mean when he writes that, in the act of creation, "NOTHING . . WILL HAVE TAKEN PLACE . . . BUT THE PLACE" (Mallarmé 1998d, 384-85; my translation). Surely this is intentionally contradictory, since he is referring to an event in which nothing takes place - except something, of course, given the "BUT." Yet that something is nothing more than the place itself, and we normally do not consider a place a something, in the sense of a thing or an event, so much as the location of a thing or event; that is, where the thing is or the event happens. True, there are those such as Henri Bergson $(2007,180)$ for whom a place is "a void limited by precise outlines, or, in other words, a kind of thing" (specifically, it is one dependent on another thing, i.e. that which takes place or is situated there). But as Mallarmé implies, in the case of creation nothing happens - except for the place itself. It is therefore hard to avoid the implication that something is missing, that there "is" an absence. This is why I interpret one sense of his "TAKEN PLACE" as referring to a place having been taken away, as if what took place led to the manifestation of "something" on par with the "hole in the air" that Leonard Cohen (1992) sings about. For even if a place is nothing, removal surely leaves less of it behind. And does not this less than nothing point to ?

Derrida seems to make virtually the same point when describing Mallarmé's use of "the blank," the gaping white spaces on some of the pages of his poetry. He sees them as cases of

white on white. The blank is coloured by a supplementary white, an extra blank that becomes . . . a blank open on all four sides, a blank that is written, blackens itself of its own accord, a false true blank sense [sens blanc], without a blank [sans blanc], no longer countable or totalizable, counting on and discounting itself at once (Derrida 1981, 260).

To count and discount at once: surely there's an extraordinary contradiction here?

I would say the same about Celan, who at times seems likewise to aim for something other than what Taylor calls a "recovery of language." Re-empowering language is what the best interpretations - and many, but not all, forms of creation aim to do. As I have suggested, however, the two are not the same in that Modernist creativity, at least, relies on inspirations coming through the interstices, the gaps,

\footnotetext{
${ }^{20}$ Hence Taylor's confusing the Saussurean theory of meaning's "unified oppositions" with Walter Benjamin's idea, later taken up by Theodor Adorno, of a "constellation" (Taylor 1989, 477-78). As a result, Taylor elides important differences between the mereological notion of life as "irreducibly multileveled" and the disunified one of its being lived on "a duality or plurality of levels, not totally compatible, but which can't be reduced to unity" (Taylor 1989, 480). (Why "but"? Surely "and so" would be better.) For more on Modernist creativity along these lines, see Blattberg 2009d, § II.ii.
} 
the . Yet when Taylor considers Celan's (2002, 125) declaration in "The Straitening [Engführung]" that "Nothing, / nothing is lost," he fails to notice the radical difference between the two nothings. Indeed, he ends up assimilating the first to the second.

As a result, strange as it may sound, Taylor's essay on Celan suffers from being overly lucid. Its coherence is only possible because he fails to account for what Aris Fioretos has called the "hermeneutic resistance" of Celan's poetry. Taylor is guilty of what Fioretos describes as the "naming of that which cannot be named," for he ignores the parts of the poems that abandon rather than revivify language, that posit the "loss of language . . . unspeakability." Because, as Fioretos writes, there are times when "Nothing is inscribed in the text, and nothing resists articulation. This nothing can hardly be hermeneutically excavated and brought to articulation, since it is passed over and covered by silence ... it cannot be turned into something meaningful" (Fioretos $1990,158,163,164,165)$.

Such Nothing cannot be made meaningful precisely because it includes the kind of contradictions implying gaps - gaps that, while serving as barriers to interpretation, can nevertheless make way for creation. Not that there is any guarantee. As an obviously frustrated Gord Downie (The Tragically Hip 2016) sings: "Nothing works / Oh and nothing works / I've tried nothing and I'm out of ideas." Downie's second "nothing," I contend, refers to

\section{CONTRADICTIONS, ORDINARY AND PARADOXICAL}

All of which should lead us to recognize two kinds of contradictions. In general, a contradiction consists of the opposition between two or more forces or ideas. When the antagonists are two or more parts of whole, I would describe the contradiction as "ordinary." Most conflicting statements, acts, or processes fall under this category, as with the many ways of expressing sweet nothings that we saw above. Or think of the contradictions of capitalism famously emphasized by Marxists. It is worth noting that these ordinary contradictions can arise within wholes across the mereological spectrum. Consider Aristotle's (2001d, 11b33-12a35) distinction between starkly opposing contraries with no intermediaries, such as numbers odd or even, and polar contraries that allow for intermediaries, such as objects ranging in colour from black to white. The former imply atomist parts, and the latter holist ones.

However, while monist thinkers assume that contradictions - when, that is, they are even willing to accept them - must take place within unified wholes, ${ }^{21}$ it should be evident that the sour nothings alluded to above are different. This is because they arise between wholes and their parts. And it is when they do, exhibiting what Bertrand Russell and Alfred North Whitehead (1997, 61-62) call "reflexiveness," that we should recognize them as paradoxical. For thats when we get the extreme perplexity - the

${ }^{21}$ As F.H. Bradley puts it, for example, "A felt contradiction which does not imply, besides its two poles, a unity which includes and is above them, will, the more it is reflected on, the more be seen to be altogether unmeaning. Unless man was and divined himself to be a whole, he could not feel the contradiction, still less feel pain in it, and reject it as foreign to his real nature.” $(1927,313)$. 
sense of absurdity, or rational unacceptability - that attends what is usually called a paradox. $^{22}$

To many, knowingly to affirm contradictions of any sort means embracing irrationality. Evidently, they assume that contradiction indicates a mistake has been made somewhere, since reality necessarily conforms to Plato (1989b, 436b8-9) and Aristotle's (2001c, IV [Gamma] 3-6, esp. 4) principle of non-contradiction. But around the world, even many monists have long rejected this view. In Greek antiquity, of course, Heraclitus and his followers not only admitted but positively affirmed contradictions as part of the unity of opposites (Kirk, Raven and Schofield 1983, ch. 6, nos. 199-209). ${ }^{23}$ Or think of the "dialectical polar monism" that has been ascribed to Aztec Nahuan metaphysics (Maffie n.d.). And among many Asian examples, one has only to contemplate Taoism's yin and yang (Lao Tzu 1963, bk. II, ch. 42) or, once again, Mahāyāna Buddhism's concept of emptiness (Conze 1957).

Among latter-day Heracliteans, those of a more holistic bent tend to go in for dialectical philosophies. To Pascal, Hegel, and Marx, for instance, progress occurs through the overcoming of contradictions in ways that maintain whatever was true in them. By contrast, more atomistic thinkers tend to reach for the formal symbols of paraconsistent logic. They believe it allows them to embrace not only contradictions involving self-reference - whether set-theoretic (e.g. Russell's paradox, with its set that is both a member of itself and not) or semantic (e.g. the liar paradox, with its statement that is both true and false) - but also those associated with certain features of the empirical world (e.g. when motion is recognized as consisting of something more than merely successive stationary instants, as if projected off a film reel) (Priest 2006, chs. 1-2, 9-12).

Graham Priest leads this atomist group, and it is revealing to contrast his idea of gaps with my own. To Priest, we should speak of gaps when it comes to certain questions about the truth value of sentences. This idea is based on Gottlob Frege's famous distinction between a term's sense, the thought it expresses, and its reference, the object it designates. On this view, a sentence has truth value if its reference is true - that is, if it successfully describes something in the world (Frege 1960, 62-63). But what about sentences that, some claim, have a meaningful sense and yet are neither true nor false? Consider "The king of France is bald." It is certainly meaningful, but as there is no king of France it seems incapable of having a truth value; this, then, is what Priest calls a "gap." 24 And as he sees it, because truth and falsity are mutually exhaustive, it

\footnotetext{
${ }^{22}$ The word "paradox" has roots in the ancient Greek paradoxon, which means merely "contrary to opinion." But it has, of course, come to express something more like "beyond rational belief." It's not for nothing that Kierkegaard declared embracing paradox to be the very definition of faith, since "faith begins precisely where thought stops" $(1983,53)$.

${ }^{23}$ It's worth noting that, when the notion of the unity of opposites is conceived as a doctrine, it serves as an instance of itself: "doctrine," a belief or set of beliefs, implies unity, and what's unified are two opposites, namely "unity" and "opposites" (when, that is, the latter implies a form of disunity).

${ }^{24}$ Many would consider as comparable self-contradictory sentences or word combinations such as "This sentence is false" or "a round square." See, for example, Husserl 2001, IV § 12; and Strawson 2004. Saul Kripke (1975) uses this idea in an attempt to solve the liar paradox - an unsuccessful attempt, given the reformulated paradox that's come to be known as the "strengthened liar."
} 
would ultimately be best to avoid such statements by asserting the truth of the sentence's negation, i.e. by saying something like "The king of France is not bald" (Priest 2006, 66-67).

My conception of a gap is much more radical. Evidently, I've been using the term alongside to point to aspects of a sentence - indeed of any being - that are not meaningful at all, or even intelligible. And these, again, arise only when there's a paradoxical contradiction between parts and whole. Think of the realization that a story's plot has "holes" in it: this indicates gaps of the radical, paradoxical sort, since there are parts of the narrative that literally do not make sense. If we limit ourselves to the essentially descriptive conception of language encouraged by Frege's distinction, however, we will miss this fundamental, and not merely referential, opacity. All the better, Priest would surely protest, since accepting inconsistency is one thing, accepting incoherence quite another. Yet the latter is precisely what I think we must sometimes do. Priest, however, would almost certainly put this down to "the babblings of a raving person" (Priest 2006, 5). ${ }^{25}$

At least I'm not alone in my madness. Consider pluralists: when it comes to the practical world, they tend to focus on how values "clash" or "collide," terms which assume gaps since they imply that the values were originally separate - that is, separated by rather than something (Berlin 2002; Hampshire 2000; Williams 1973; Williams 1981). Then again, because pluralists tend to be attracted to atomism mereologically, and so to an emphasis on independent parts, they generally see such conflicts as contradictory but not especially perplexing. That's why they tend to miss the profound kind of confusion that arises, again, in the face of more holistic conflicts, the kind based on the paradoxical opposition between part and whole.

Regarding what used to be called natural philosophy, for instance, this is why it seems perfectly understandable for Lucretius, say, to view conflict as constructive. To him, when swerving atoms collide, they will occasionally combine to produce compound bodies; then, when films of atoms slough off one of these bodies and "smite" our sensory organs, they produce sense perception (Lucretius 2007, II.216-93, IV.217721). Closer to our own time, quantum physicists have determined that decoherence, the collapse of an isolated system's wave function, arises whenever there's a thermodynamically irreversible "collision" between the system and its environment. ${ }^{26}$ Yet this kind of talk only makes sense if we subscribe to a pluralist version of the Copenhagen interpretation - one that rules out monist ideas such as the existence of "hidden variables," i.e. as-yet unknown elements of reality connecting entities that currently appear isolated (Bohm 1952). (Once such variables are uncovered, the claim goes, our universe will be revealed as free of gaps.) Also ruled out is the monist theory of many - perhaps infinite - worlds, one for every possible case of quantum

\footnotetext{
${ }^{25}$ Regarding his monism, see Priest 2014, chs. 11-15.

${ }^{26}$ One might wonder why talk of isolated systems is appropriate, given the non-locality of quantum entanglement. But apparently, during decoherence the colliding entities are not at all entangled. See e.g., Ziman and Bužek 2011, 216.
} 
decoherence (Everett 1957). ${ }^{27}$ Regardless, talk of collisions makes one think of originally independent entities having come together - a mereological atomism that, once again, has room for ordinary contradictions but not for the paradoxical kind.

Returning to ethics, the pluralist's assumption that values can be at best balanced against each other implies that any such accommodation serves to cover over the gaps like a "bandage." Or we may see it as the kind of political settlement that, thanks to the willingness of good-faith negotiators to make compromises, successfully "bridges" differences. Both metaphors can be used to indicate that, while something has been extended over a space, the space remains. Evidently, this is different from the monistic dialectical approaches mentioned above, since the absence of gaps is behind why they are much more comfortable speaking of progressive resolutions instead. Nor would they agree with the pluralist who recognizes that, in the worst case when no accommodation is possible - both practically but also in principle - we will have no choice but to accept the (potentially catastrophic, and so tragic) conflict. Still, even then, the tendency is for pluralists to have us speak not of paradox but simply of irresolvable contradiction. Which is understandable, since if one tends to see the world as no more than a fragmented place of often-irreconcilable atomic bits, then while this may bring occasional feelings of sadness, or at least disappointment, there's nothing especially perplexing about it.

By contrast, to those thinkers who I call "pluramonists" (for lack of a better term), existence can exhibit now a oneness, now a manyness - which, in extremis, can reach a point of such total disintegration that it becomes . This makes it paradoxical indeed. Sometimes, such a view is accompanied by no more than a playfully ironic attitude; sometimes, the gaps in the whole are seen as potential openings for creativity, as we saw above; and sometimes we get both together.

That last pluramonist variation can give rise to a conception of creativity along the lines of mere play, as "just gaming," which is Jean-François Lyotard's view (Lyotard and Thébaud 1985, 36, 41, 43, 59). But since players need to share a consensus over the rules, and so should be seen as in that sense unified, we ought to wonder about the dulling effects of this approach on any paradox. ${ }^{28}$ Similarly, Hannah Arendt has recommended a form of creativity-as-spectacle through the putting on of a glorious political show, one made possible by the paradoxical space generated whenever citizens come together - a space, as she puts it, "that simultaneously gathers them into

\footnotetext{
${ }^{27}$ That the theory is monist would have been easier to detect had it been given a different name. Indeed, according to Roger Penrose (2004, 784, 798), it should have been called "omnium" (from the Latin for "of all"), although the reason he gives for this is strictly numerical: "the alternative worlds do not really 'exist' separately, in this view; only the vast particular superposition expressed by $|\psi\rangle$ is taken as real . . . The ontologically 'real' omnium (described by $|\psi\rangle$ ) is a superposition of numerous different worlds, and the collection of all these individual worlds (rather than just their particular superposition $|\psi\rangle)$ is not to be taken as 'real'."

${ }^{28}$ As Emmanuel Levinas senses, I believe. Lyotard (Lyotard and Thébaud 1985, 60-61) has taken him to task for privileging one language game, that of ethics, above all others. But I think Levinas would (rightly) reply that "Saying is not a game" (Levinas 1991, 5).
} 
it and separates them from one another" (Arendt 2005, 106). ${ }^{29}$ But this can sound very much like the mending wall form of separation that, as noted above, is anything but paradoxical. By contrast, Theodor Adorno (1997, 1-15, 225-61) manages to avoid any such degradation to unity, and so aestheticization of the artistic process (as strange as that may sound), when he writes of creation as implying a necessary, if periodic, separation between the creative act and society. For the demarcation line he traces between the two flashes in and out of existence - what I think he means by art's "double character." It's for this reason that Adorno can be said to consider what is left behind during the moments it is gone as less than nothing, and so as a gap of

Finally, apart from pluralism and pluramonism, there is at least one remaining nonmonistic alternative to nihilism: the in-between approach that I favour. It should be situated somewhere in the interval of monism and pluralism given that it would have us move "towards One, as many." It can (partly) go along with pluramonist philosophers when it comes to creativity, as well as with pluralists when it comes to negotiating accommodations - because, sometimes, that is indeed the best we can do. But sometimes we can do better. To the value pluralist, as we've seen, when faced with a genuine conflict mere damage control is the height of ambition. But what if, instead of merely bandaging a gap with an accommodation, we can truly "heal" it, that is, close the by reconciling the conflict through a transformation of the whole? Is it possible that, by changing the meanings at stake, we can - at least on occasion - overcome the paradox, and thereby help repair the world? I believe so.

\section{BETWEEN MONISM AND PLURALISM}

How might this approach work? It consists of resolving paradoxes by removing the gaps, not merely covering them over.

For an example of reconciliation-through-transformation, consider a famous story. "'Holmes', I cried. 'Is it really you? Can it indeed be that you are alive? Is it possible that you succeeded in climbing out of that awful abyss?" (Conan Doyle 2005, 790). These are Dr. John H. Watson's first words to the friend he's presumed dead for three years, ever since Sherlock Holmes' struggle with his arch-enemy Professor Moriarty at the Reichenbach Falls.

Apparently, Arthur Conan Doyle originally decided to kill off his best-known character in order to focus on more serious literary work. But public pressure led him to resurrect the famous sleuth - which brought with it the problem of accounting for Holmes' intervening absence. In the first story set after Reichenbach, Conan Doyle establishes that the detective kept his survival a secret from his best (and only) friend. Holmes offers this explanation:

I owe you many apologies, my dear Watson, but it was all-important that it should be thought I was dead, and it is quite certain that you would not have written so convincing an account of my unhappy end had you not yourself thought that it was true. Several times

\footnotetext{
${ }^{29}$ She also says that the space both "relates and separates" people, thereby making way for "the paradoxical plurality of unique beings" (Arendt 1998, 52, 176).
} 
during the last three years I have taken up my pen to write to you, but always I feared lest your affectionate regard for me should tempt you to some indiscretion which would betray my secret (Conan Doyle 2005, 793).

Holmes claims that a convincing account of his death was necessary to make his remaining enemies drop their guard so he could dispatch them. But this is extremely weak. After all, he reappears long after Watson had published his account. The definitive BBC radio adaptation of the story makes exactly this point: Watson himself asks "What about after it was published?" and Holmes haplessly replies "Still too great a risk - for you as well as me. Hmm? I can only ask your forgiveness" (Conan Doyle and Coules 2017, starting at 27:08). Surely Watson could have kept his confidence - particularly since it wasn't even such a secret. In Conan Doyle's original version, Holmes mentions confiding quickly in his brother Mycroft, who's since funded years of international travel and research. One of Professor Moriarty's confederates also witnessed his escape, Holmes recounts, and tried to kill him as he hid on a ledge at the Falls. So quite a few people must have known he was alive. Why, then, didn't Holmes tell Watson earlier?

All this confronts alert readers with a hole - and so a gap - in the plot and its meaning. This has sometimes prompted remarkable ingenuity: Robert Keller (1975), for example, has speculated that Holmes actually died at the Reichenbach Falls, only returning to Watson three years later as a dissembling ghost. But the best explanation I've come across points to irrationality, driven by jealously. For Holmes chose to return only after the death of Watson's wife, Mary Marsden. Indeed, many have suspected that Holmes and Watson are lovers. Literary critic Graham Robb (2003, 260) confidently declares "Everyone already knows, instinctively, that Holmes is homosexual." And Conan Doyle's characters are certainly popular subjects of "slash" fiction - fan-authored romance and erotica that queers pop narratives, reimagining main characters as acting on same-sex attraction. ${ }^{30}$ This makes sense of Holmes' behaviour and so closes the plot hole, via a radical reinterpretation of the partners' underlying relationship.

It's also a truly transformative account. Pluralist critics would never go so far; at most, they would struggle towards an interpretation that minimized the incongruities by degree, perhaps until a better explanation came along. This might involve building, say, on Conan Doyle's suggestion that Holmes would have tried to reach Watson but for investigative necessity. Or we could invoke Keller's speculation again, noting that its reliance on the supernatural compromises a background assumption of the whole Sherlock Holmes canon.

By contrast, my approach can be seen as invoking a form of practical reason modelled on conversation rather than negotiation. Because when interlocutors genuinely listen to each other with open minds, they may find a way to reconcile their conflicts. And unlike accommodation, such reconciliations do not involve compromise.

\footnotetext{
30 The term "slash" comes from Star Trek (1966-present) fandom, whose amateur authors began the practice of indicating sexual content in fan publications with a slash in the title, e.g. "Kirk/Spock."
} 
On the contrary, they are win-win, emerging from synergies rather than mutual concession.

Reconciliation doesn't return us to some idyllic paradise, however. We arrive instead at that harmonious state characteristic of the prereflective, which is exhibited by habitual practices. In such activities, meanings are concordant enough to go unnoticed; they simply do not "show up" for us.

To achieve such harmony, it helps if we conceive of the conflicts that check it as a form of dissonance, rather than the adversarial clash of originally separate entities. While the latter approach treats conflicting values as isolated, the former takes them to be parts of a holistic whole - the good they share in common. This means that they're not definable independently, say with a set of necessary and sufficient conditions. Instead, for interlocutors interested in reconciliation, making distinctions seems the best way to grasp dissonant values. Distinctions are more holistic because they imply contrastive definitions. And just as dictionaries define words with other words from the same language, there's a sense in which this leaves the whole present in each part. ${ }^{31}$ So the holism here is organic, even if the whole is disunified or "broken" because of some conflict.

The question - and challenge - of reconciliation thus becomes whether it's possible to repair the gap between parties, or meanings, in conflict, bringing the whole closer towards a unified state. When the gap in the whole can be imagined as going all the way through, it's a sign that the conflict may be irreconcilable. Or not. Still, an essential difference here from monist approaches is the fact that there is no guarantee of reconciliation, even in principle.

Another arises from diverging conceptions of resolution-bringing change. I want to conclude by identifying five forms of this popular with monists.

Mixing, according to Aristotle (2001a, 328b23-24), brings unification through alteration. The result when thorough is homogeneous uniformity, with the parts losing their uniqueness and becoming, at most, portions, and the whole coming to form more of a magnitude than a multitude. So mixing detracts from difference, in contrast to meaningful reconciliations.

Regeneration is a form of transformation, but it is both more limited and not as forward-looking as the version I wish to advance. Yes, regeneration implies healing or "making whole." But it does so through a return: renewing some prior form of existence, as expressed in the word's Latin root ("to create again"). So when proponents of the French Enlightenment used the term in reference to their hoped-for transformation of the social and political world, they alluded to the Christian ideas of rebirth and resurrection (Starobinski 1976, 562). And just as doctrine can lead Christians to accept rather than overcome paradoxes such as the Trinity, regeneration in general can do no more than this.

Realisation is likewise not especially forward-looking, since any possibility realised is presumably latent in whatever already is. This applies even when the term is associated with a developmental process that's both unending and open to its

\footnotetext{
${ }^{31}$ Wilhelm von Humboldt expresses this idea with his metaphor of language as a web: touch one part, and the whole resonates $(1988,31)$.
} 
environment, as with Hegel's conception of Bildung (Bykova 2020). It also implies a differentiation of the whole through reconciliations that are, in principle, always possible. This informs the Hegelian dialectician's idea that nothing discarded ever has real value. True, we may (or may not) feel sorrow over the perishing of partial realities along the way, but all determinate being is finite, and finitudes are mortal by definition; thankfully, Geist the whole lives on, advancing forever (Hegel 2010, 21.116-21.124). Marx also saw historical progress in this pitiless light, which is why he was able to quote Goethe on empire:

Should this torture then torment us Since it brings us greater pleasure?

Were not through the rule of Timur

Souls devoured without measure? (Marx 1853)

If the process is driven by genuine conflict, though, there ought to be a risk of real loss, even alongside progress. Those who sometimes rely on radical transformation of the kind I'm advocating know this. They're also aware that there is nothing inevitable about it; on the contrary, it could easily fail. Because reconciliation, once again, is never guaranteed.

Reconfiguration, central to Heidegger's conception of the artistic process, enables a significant degree of originality. But it's also more limited and less novel than what I'm calling transformation, since it never goes beyond the reformulation of alreadyexisting meaning. As Heidegger $(1997,17,21,18)$ himself puts it, we can never transcend "thinking as such," which is necessarily "delivered over to the being which already is"; so we must accept that "finite knowledge is noncreative intuition." Originality, for him, thus ends-up being no more than the manifestation of a neverfully-disclosable "earth," which is a principle of reserve (Heidegger 1971b, 47). As such, it is not radical enough to allow overcoming paradox.

This is even more true of reflective equilibrium. As described by John Rawls, the aim here is for theorists to adjust both principles and considered judgments in pursuit of a more coherent, systematic whole. But to do so, he points out, they must award certain principles or judgments the status of "provisional fixed points" (Rawls 1999, 18). ${ }^{32}$ This is an important limitation, and it stands alongside at least one other: when something upsets the system, the goal is always a return to the original equilibrium (in Rawls' case, to the one associated with his already-developed theory of justice). So while there may be adjustments along the way, in the best case they amount to a goingback. ${ }^{33}$ And even when it manages this, reflective equilibrium still doesn't suffice to

32 This is also true of Willard Van Orman Quine's early conception of an empirical system's development: while "no statement is immune to revision," when a recalcitrant experience needs to be accommodated, it may be done through "any of various alternative re-evaluations in various alternative quarters of the total system" - the implication being that not all quarters will be implicated (Quine 1980, $43,44)$.

${ }^{33}$ Complexity theorists distinguish such "conservative" systems from "dissipative" ones, since only the latter dissipate into the environment around them through a fundamental reconfiguration of their structures (Nicolis and Prigogine 1989, ch. 2, § 1-2). 
overcome paradox; on the contrary, when confronted by one, the necessity of maintaining systematic unity overall leaves this approach powerless. It can do nothing but nothing.

By beginning with Holmes and ending with Rawls, I hope to have shown how the in-between approach I favour is relevant to a very wide variety of narrative forms, from the fictional to the political. After all, gaps and the paradoxes based upon them can arise within all sorts of texts and text-analogues. My claim has been that each requires a truly transformative approach if it is to be closed and resolved. Not that there is any warrant for monist optimism. But nor should we be resigning ourselves to pluralist pessimism.

\section{ACKNOWLEDGEMENTS}

The author would like to express his gratitude particularly for the peer reviewing of this paper.

\section{REFERENCES}

Adorno, Theodor (1997), Aesthetic Theory, (eds) Gretta Adorno and Rolf Tiedmann, trans. Robert Hullot-Kentor (Minneapolis: University of Minnesota Press).

Arendt, Hannah (1998), The Human Condition (Chicago: University of Chicago Press, 2nd ed.).

Arendt, Hannah (2005), "Introduction into Politics," in The Promise of Politics, (ed.) Jerome Kohn (New York: Schocken Books), 93-200.

Aristotle (2001a), On Generation and Corruption, trans. Harold H. Joachim, in The Basic Works of Aristotle, (ed.) Richard McKeon (New York: Random House), 470534.

Aristotle (2001b), Physics, trans. R.P. Hardie and R.K. Gaye, in The Basic Works of Aristotle, (ed.) Richard McKeon (New York: Random House), 213-394.

Aristotle (2001c), Metaphysics, trans. W.D. Ross, in The Basic Works of Aristotle, (ed.) Richard McKeon (New York: Random House), 681-926.

Aristotle (2001d), Categories, trans. E.M. Edghill, in The Basic Works of Aristotle, (ed.) Richard McKeon (New York: Random House), 3-37.

Augustine (1995), The Teacher (389), in Against the Academicians and The Teacher, (ed. and trans.) Peter King (Indianapolis, IN: Hackett Publishing Company), 94146.

Bergson, Henri (2007 [1907]), Creative Evolution, (eds) Keith Ansell Pearson; Michael Kolkman; and Michael Vaughan, trans. Arthur Mitchell (New York: Palgrave Macmillan).

Berlin, Isaiah (2002), Liberty: Incorporating Four Essays on Liberty, (ed.) Henry Hardy (Oxford: Oxford University Press). 
Blattberg, Charles (2009a), "The Ironic Tragedy of Human Rights", in Patriotic Elaborations: Essays in Practical Philosophy (Montreal and Kingston: McGillQueen's University Press), 43-59.

Blattberg, Charles (2009b), "Good, Bad, Great, Evil", in Patriotic Elaborations: Essays in Practical Philosophy (Montreal and Kingston: McGill-Queen's University Press), 190-210.

Blattberg, Charles (2009c), "Opponents vs. Adversaries in Plato's Phaedo", in Patriotic Elaborations: Essays in Practical Philosophy (Montreal and Kingston: McGill-Queen's University Press), 211-28.

Blattberg, Charles (2009d), "What's Wrong with Hypergoods?" in Patriotic Elaborations: Essays in Practical Philosophy (Montreal and Kingston: McGillQueen's University Press), 122-45.

Blattberg, Charles (2009d), "On the Minimal Global Ethic", in Patriotic Elaborations: Essays in Practical Philosophy (Montreal and Kingston: McGill-Queen's University Press), 146-89.

Blattberg, Charles (forthcoming), "Antisemitism and the Aesthetic".

Bohm, David (1952), "A Suggested Interpretation of the Quantum Theory in Terms of 'Hidden Variables' I", Physical Review 85.2: 166-79. <https://doi.org/ 10.1103/ PhysRev.85.166>

Bradley, F.H. (1927), “Concluding Remarks", in Ethical Studies (Oxford: Oxford University Press, 2nd ed.).

Brassier, Ray (2007), Nihil Unbound: Extinction and Enlightenment (New York: Palgrave Macmillan).

Brater, Enoch (2010), "Coda: The No-Thing that Knows No Name and the Beckett Envelope, Blissfully Reconsidered”, in Daniela Caselli (ed.), Beckett and Nothing: Trying to Understand Beckett (Manchester: Manchester University Press), 237-44.

Brooks, William (2007), "Pragmatics of Silence", in Nicky Losseff and Jenny Doctor (eds), Silence, Music, Silent Music (Burlington, VT: Ashgate), 97-126.

Bykova, Marina F. (2020), "Hegel's Philosophy of Bildung," in Bykova and Kenneth R. Westphal (eds), The Palgrave Hegel Handbook (Cham, Switzerland: Springer Nature), 425-49.

Cage, John (2011 [1961]), "Lecture on Nothing", in Silence: Lectures and Writings (Middletown, CT: Wesleyan University Press, new ed.), 109-27.

Carroll, Lewis (1965 [1866]), Alice's Adventures in Wonderland (New York: Random House).

Celan, Paul (2002), "The Straitening [Engführung]", in Poems of Paul Celan, trans. Michael Hamburger (New York: Persea Books, rev. ed.), 137.

Clifton, Thomas (1976), "The Poetics of Musical Silence", The Musical Quarterly 62.2: 163-81. <https://doi.org/10.1093/mq/LXII.2.163>

Cohen, Leonard (1992), "Democracy", from the album The Future (New York: Columbia Records).

Conan Doyle, Arthur (2005), "The Adventure of the Empty House (1903)," in The New Annotated Sherlock Holmes: Volume II, (ed.) Leslie S. Klinger (New York: W.W. Norton \& Co.), 781-828. 
Conan Doyle, Arthur and Bert Coules (dramatizer) (2017), "The Empty House (1993)", in The Return of Sherlock Holmes (London: BBC Worldwide).

Conze, Edward (ed. and trans.) (1958), "The Heart Sutra", in Buddhist Wisdom Books (New York: Harper \& Row), 77-107.

Cooper, Barry (2011), "Beethoven's Uses of Silence”, Musical Times 152.1914: 2543. <https://www.jstor.org/stable/23039954>

Dan, Joseph (1998-99), "The Paradox of Nothingness in the Kabbalah", in Jewish Mysticism, vol. 4: General Characteristics and Comparative Studies (Northvale, NJ and London: Jason Aronson), 63-69.

Deguy, Michel (1998), "The Energy of Despair", in Robert Greer Cohn and Gerald Gillespie (eds), Mallarmé in the Twentieth Century (Cranbury, NJ: Associated University Presses), 19-30.

Derrida, Jacques (1978), "Violence and Metaphysics: An Essay on the Thought of Emmanuel Levinas", in Writing and Difference, trans. Alan Bass (Chicago: University of Chicago Press), 79-153.

Derrida, Jacques (1981), "The Double Session," in Dissemination, trans. Barbara Johnson (Chicago: University of Chicago Press), 173-286.

Everett, Hugh (1957), “Relative State' Formulation of Quantum Mechanics", Reviews of Modern Physics 29.3: 454-62. <https://doi.org/10.1103/ RevModPhys.29.454>

Fioretos, Aris (1990), "Nothing: Reading Paul Celan's 'Engführung'", Comparative Literature Studies 27.2: 158-68. <https:/www.jstor.org/stable/40246744>

Frege, Gottlob (1960), "On Sense and Reference (1892)", trans. Max Black, in Translations from the Philosophical Writings of Gottlob Frege, (eds) Black and P.T. Geach (Oxford: Basil Blackwell, 2nd ed.), 56-78.

Fridugisus of Tours (1995 [800]), On the Being of Nothing and Shadows, trans. Paul Vincent Spade (Bloomington: Department of Philosophy, Indiana University). $<$ http://www.pvspade.com/Logic/docs/fridugis.pdf $>$

Garfield, Jay L. (2015), Engaging Buddhism: Why It Matters to Philosophy (Oxford: Oxford University Press).

Guarisco, Donald A. (n.d.), Review of The Best Years of Our Lives, AllMusic. $<$ https://www.allmusic.com/album/the-best-years-of-our-lives-mw0000364834>

Guth, Alan H. (1997), The Inflationary Universe: The Quest for a New Theory of Cosmic Origins (New York: Basic Books).

Hampshire, Stuart (2002), Justice is Conflict (Princeton: Princeton University Press).

Harris, Ellen T. (2005), "Silence as Sound: Handel's Sublime Pauses", Journal of Musicology 22.4: 521-58. <https://doi.org/10.1525/jm.2005.22.4.521>

Hegel, G.W.F. (2010 [1830]), Encyclopedia of the Philosophical Sciences in Basic Outline: Part I, Science of Logic, (eds and trans.) Klaus Brinkman and Daniel O. Dahlstrom (Cambridge: Cambridge University Press).

Hegel, G.W.F. (2010 [1812]), The Science of Logic, trans. George Di Giovanni (Cambridge: Cambridge University Press).

Heidegger, Martin (1962 [1927]), Being and Time, trans. John Macquarrie and Edward Robinson (Oxford: Blackwell). 
Heidegger, Martin (1971a), "The Thing", in Poetry, Language, Thought, trans. Albert Hofstadter (New York: Harper \& Row), 163-86.

Heidegger, Martin (1971b), "The Origin of the Work of Art", in Poetry, Language, Thought, trans. Albert Hofstadter (New York: Harper \& Row), 15-88

Heidegger, Martin (1987), An Introduction to Metaphysics, trans. Ralph Manheim (New Haven: Yale University Press).

Heidegger, Martin (1997), Kant and the Problem of Metaphysics, trans. Richard Taft (Bloomington: Indiana University Press, 5th ed.).

Heidegger, Martin (2008), "What Is Metaphysics? (1929)", trans. David Farrell Krell, in Basic Writings, (ed.) Krell (New York: HarperCollins, new ed.), 89-110.

Heisig, James W. (2001), Philosophers of Nothingness: An Essay on the Kyoto School (Honolulu: University of Hawaii Press).

Holt, Jim (2012), Why Does the World Exist? An Existential Detective Story (New York: W.W. Norton \& Co.)

Howard, Don (1997), "A Peek behind the Veil of Maya: Einstein, Schopenhauer, and the Historical Background of the Conception of Space as a Ground for the Individuation of Physical Systems", in John Earman and John D. Norton (eds), The Cosmos of Science: Essays of Exploration (Pittsburgh: University of Pittsburgh Press).

Humboldt, Wilhelm von (1988 [1836]), On Language: On the Diversity of Human Language Construction and Its Influence on the Mental Development of the Human Species, trans. Peter Heath (Cambridge: Cambridge University Press).

Husserl, Edmund (2001 [1913]), Logical Investigations, vol. 2, (ed.) Dermot Moran, trans. J.N. Findlay (London: Routledge, new ed.).

Jefferson, Thomas (1998), "Jefferson's Letter to the Danbury Baptists: The Final Letter, as Sent (1 January 1802)," Library of Congress: Information Bulletin 57.6. $<$ https://www.loc.gov/loc/lcib/9806/danpre.html>

Katsafans, Paul (2015), "Fugitive Pleasure and the Meaningful Life: Nietzsche on Nihilism and Higher Values", Journal of the American Philosophical Association 1.3: $396-416$.

Keller, Robert (1975), “Sherlock Holmes: A Spectra?” Baker Street Journal 25.3: 160_ $61,167$.

Kierkegaard, Søren (1978), The Present Age (1846), in Two Ages: The Age of Revolution and The Present Age, A Literary Review, (eds and trans.) Howard V. and Edna H. Hong (Princeton: Princeton University Press), 68-112.

Kierkegaard, Søren (1983), Fear and Trembling (1843), in Fear and Trembling and Repetition, (eds and trans.) Howard V. and Edna H. Hong (Princeton: Princeton University Press), 1-123.

Kirk, G.S., J.E. Raven, and M. Schofield (1983), The Presocratic Philosophers: A Critical History with a Selection of Texts (Cambridge: Cambridge University Press, 2nd ed.).

Kitarō, Nishida (1987 [1945]), "The Logic of the Place of Nothingness and the Religious Worldview", in Last Writings: Nothingness and The Religious 
Worldview, trans. David A. Dilworth (Honolulu: University of Hawaii Press), 47123.

Kripe, Saul (1975), "Outline of a Theory of Truth”, Journal of Philosophy 72.19: 690716. <https://doi.org/10.2307/2024634>

Lao Tzu (1963), Tao Te Ching, trans. D.C. Lau (Harmondsworth: Penguin Books).

Levinas, Emmanuel (1991), Otherwise than Being or Beyond Essence, trans. Alphonso Lingus (Boston: Kluwer Academic Publishers).

Locke, John (1975 [1689]), An Essay Concerning Human Understanding, (ed.) Peter H. Nidditch (Oxford: Oxford University Press).

Lucretius (2007), The Nature of Things, trans. Alicia E. Stallings (London: Penguin).

Lyotard, Jean-François and Jean-Loup Thébaud (1985), Just Gaming, trans. Wlad Godzich (Minneapolis: University of Minnesota Press).

Maffie, James (n.d.), "Aztec Philosophy" Internet Encyclopedia of Philosophy. $<$ http://www.iep.utm.edu/aztec/\#H1>.

Mallarmé, Stéphane (1998a), Igitur ou La folie d'Elbehnon, in Euvres complètes, vol. 1 (ed.) Bertrand Marchal (Paris: Gallimard), 471-500.

Mallarmé, Stéphane (1998b), 16 November 1885 letter to Paul Verlaine, in CEuvres complètes, vol. 1. (ed.) Bertrand Marchal (Paris: Gallimard), 786-90.

Mallarmé, Stéphane (1998c), 13 July 1866 letter to Henri Cazalis, in Euvres complètes, vol. 1 (ed.) Bertrand Marchal (Paris: Gallimard), 701-702.

Mallarmé, Stéphane (1998d), "Un coup de Dés jamais n'abolira le Hasard", in Euvres complètes, vol. 1, (ed.) Bertrand Marchal (Paris: Gallimard), 363-402.

Matt, Daniel C. (2000), "Ayin: The Concept of Nothingness in Jewish Mysticism”, in Lawrence Fine (ed.) Essential Papers on Kabbalah (New York: NYU Press), 67108.

Margulis, Elizabeth Hellmuth (2007), "Moved by Nothing: Listening to Musical Silence", Journal of Music Theory 51.2: 245-76. <https://doi.org/10.1215/ 00222909-2009-003>

Marx, Karl (1853), “The British Rule in India," New York Daily Tribune, 25th June. $<$ https://www.marxists.org/archive/marx/works/1853/06/25.htm>

Marx, William (2010), “John Cage's 4'33"'”, performed at McCallum Theatre, Palm Desert, CA. <https://www.youtube.com/watch?v=JTEFKFiXSx4\&ab_chanel= Joel Hochberg $>$

Nicolis, Grégoire and Ilya Prigogine (1989), Exploring Complexity: An Introduction (New York: W.H. Freeman and Co.).

Nietzsche, Friedrich (2001 [1882]), The Gay Science: With A Prelude in German Rhymes and an Appendix of Songs, (ed.) Bernard Williams, trans. Josefine Naucoff and Adrian Del Caro (Cambridge: Cambridge University Press).

Nietzsche, Friedrich (2006 [1885]), Thus Spoke Zarathrustra: A Bookfor All and None, (eds) Adrian del Caro and Robert B. Pippen, trans. del Caro (Cambridge: Cambridge University Press).

Osterweis, Marian, Frederic Solomon, and Morris Green (1984), Bereavement: Reactions, Consequences, and Care (Washington, DC: National Academy Press).

Pascal, Blaise (2003 [1670]), Pensées, trans. W.F. Trotter (Mineola, NY: Dover). 
Peattie, Thomas (2015), Gustav Mahler's Symphonic Landscapes (Cambridge: Cambridge University Press).

Penrose, Roger (2004), The Road to Reality: A Complete Guide to the Laws of the Universe (New York: Random House).

Priest, Graham (2006), In Contradiction: A Study of the Transconsistent (Oxford: Oxford University Press, 2nd ed.).

Priest, Graham (2014), One: Being an Investigation into the Unity of Reality and of its Parts, including the Singular Object which is Nothingness (Oxford: Oxford University Press).

Plato (1989a), Sophist, trans. F.M. Cornford, in The Collected Dialogues of Plato: Including the Letters, (eds) Edith Hamilton and Huntington Cairns (Princeton: Princeton University Press).

Plato (1989b), Republic, trans. F.M. Cornford, in The Collected Dialogues of Plato: Including the Letters, (eds) Edith Hamilton and Huntington Cairns (Princeton: Princeton University Press).

Quine, Willard Van Orman (1980), "Two Dogmas of Empiricism", in From a Logical Point of View: 9 Logico-Philosophical Essays (Cambridge, MA: Harvard University Press, 2nd ed.).

Rawls, John (1999), A Theory of Justice (Cambridge, MA: Harvard University Press, rev. ed.).

Redekop, Magdalene (2013), "Farm Animals' Desertion: In Which Puss in Boots Learns That the Kota Is Full", CMW Journal 5.4: 1-13. <https://mennonite writing.org/journal/5/4/farm-animals-desertion/\#all>

Ricci, Michael et al. (2005), "The Role of Silence in Music," all about jazz. <https:// www.allaboutjazz.com/the-role-of-silence-in-music-by-aajstaff.php>

Robb, Graham (2003), Strangers: Homosexual Love in the Nineteenth Century (New York: W.W. Norton \& Co.).

Russell, Bertrand and Alfred North Whitehead (1997 [1927]), Principia Mathematica: To *56 (Cambridge: Cambridge University Press).

Sallis John (1987), Spacings - of Reason and Imagination in Texts of Kant, Fichte, Hegel (Chicago: University of Chicago Press).

Sartre, Jean-Paul (1956), Being and Nothingness: A Phenomenological Essay on Ontology, trans. Hazel E. Barnes (New York: Washington Square Press).

Sartre, Jean-Paul (1988), Mallarmé, or the Poet of Nothingness, trans. Ernest Sturm (Philadelphia: Pennsylvania State University Press).

Scholem, Gershom (1974), Major Trends in Jewish Mysticism (New York: Schocken Books).

Sedley, David (1982), “Two Conceptions of Vacuum”, Phronesis 27.1-2: 175-93. $<$ https://doi.org/10.1163/156852882X00113>

Sen, Amartya (1999), "Human Rights and Asian Values", in Joel H. Rosenthal (ed.), Ethics \& International Affairs: A Reader (Washington, DC: Georgetown University Press, 2nd ed.), 170-93.

Shakespeare, William (1977 [1623]), Macbeth, (ed.) Roma Gill (Oxford: Oxford University Press). 
Starobinski, Jean (1976), “Éloquence et liberté," Revue suisse d'histoire 26.4: 549-66. $<$ http://doi.org/10.5169/seals-80755>

Stevens, Wallace (1997a), “The Snow Man", in Wallace Stevens: Collected Poetry and Prose, (eds) Frank Kermode and Joan Richardson (New York: Library of America), 8.

Stevens, Wallace (1997b), “The Course of a Particular”, in Wallace Stevens: Collected Poetry and Prose, (eds) Frank Kermode and Joan Richardson (New York: Library of America), 460.

Strawson, P.F. (2004 [1971]), “On Referring”, in Logico-Linguistic Papers (London: Methuen, 2nd ed.), 1-20.

Swift, Daniel (2015), "Hide and Seek with T.S. Eliot," The Spectator, 15 December. $<$ https://www.spectator.com.au/2015/12/hide-and-seek-with-t-s-eliot/>

Taylor, Charles (1989), Sources of the Self: The Making of the Modern Identity (Cambridge, MA: Harvard University Press).

Taylor, Charles (2007), A Secular Age (Cambridge, MA: Harvard University Press).

Taylor, Charles (2014), "Celan and the Recovery of Language", in Dilemmas and Connections: Selected Essays (Cambridge, MA: Harvard University Press), 56-77.

Taylor, Charles (2016), The Language Animal: The Full Shape of the Human Linguistic Capacity (Cambridge, MA: Harvard University Press).

The Tragically Hip (2016), "Great Soul”, from the album Man Machine Poem (Toronto: Universal Music).

Valéry, Paul (1968), "Variations on a Pensée (1923)," in The Collected Works of Paul Valéry, vol. 9: Masters and Friends, (ed.) Jackson Matthews, trans. Martin Turnell (Princeton: Princeton University Press), 86-109.

Valéry, Paul (1971), "Silhouette of a Serpent (1922)", in The Collected Works of Paul Valéry, vol. 1: Poems, (ed.) James R. Lawler, trans. David Paul (Princeton: Princeton University Press), 184-205.

Valéry, Paul (2011), Valéry's Graveyard: Le Cimitière marin, trans. Hugh P. McGrath and Michael Comenetz (New York: Peter Lang Publishing).

Varzi, Achille C. (2015), "The Magic of Holes", in Giuseppina Marsico and Luca Tateo (eds), Ordinary Things and Their Extraordinary Meanings (Charlotte, NC: Information Age Publishing), 21-34.

Vilenkin, Alexander (1982), "Creation of Universes from Nothing," Physics Letters 117B.1-2: 25-28. <https://doi.org/10.1016/0370-2693(82)90866-8>

Vilenkin, Alexander (2006), Many Worlds into One: The Search for Other Universes (New York: Farrar, Straus and Giroux).

Walzer, Michael (1983), Spheres of Justice: A Defense of Pluralism and Equality (New York: Basic Books).

Walzer, Michael (2007), "Liberalism and the Art of Separation", in Thinking Politically: Essays in Political Theory, (ed.) David Miller (New Haven: Yale University Press), 53-67.

Welton, Donn (2002), The Other Husserl: The Horizons of Transcendental Philosophy (Bloomington: Indiana University Press). 
Williams, Bernard (1973), "Ethical Consistency", in Problems of the Self: Philosophical Papers 1956-1972 (Cambridge: Cambridge University Press), 16686.

Williams, Bernard (1981), "Conflicts of Values", in Moral Luck: Philosophical Papers 1973-1980 (Cambridge: Cambridge University Press), 71-82.

Williams, Bernard (1993), Shame and Necessity (Berkeley: University of California Press).

Ziman, M. and V. Bužek (2011), "Open System Dynamics of Simple Collision Models", in Robert Olkiewicz et al. (eds), Quantum Dynamics and Information (Hackensack, NJ: World Scientific), 199-228. 